\title{
A CONCEPTUAL STUDY ON PAKSHAGHATE TU VIRECHANAM WITH SPECIAL REFERENCE TO BRIHATRAYEE
}

\section{Dr. Arup Jyoti Das}

\section{Dr. KanikaGoswami}

PG Scholar, Dept. of SamhitaSiddhanta, Govt. Ayurvedic College, Guwahati-14, Assam. ${ }^{*}$ Corresponding Author

Assistant Professor, Dept. of SamhitaSiddhanta, Govt. Ayurvedic College, Guwahati-14, Assam

ABSTRACT Pakshaghata is one among the vatavyadi, considered under astamahagada, which is swabhavatahduschikitsya. When the greatly aggravated vata invades the urdhwa, adha and thiryakgatadhamanis, then it destroys any one half of the body which is called as pakshaghata. By this, affected side of the body becomes incapable of any work. In Vatavyadhi, basti is considered as the best treatment, but for pakshaghatasneha is the line of treatment. Acharya charaka also explained swedana and snehayuktavirechana in pakshagata. So, Erandataila is selected for virechana in the patients suffering from pakshaghata.Virechana is the chiefly advocated, purificatory measure in this disease and all the acharyas mentioned, virechana is one among the chief line of treatment for pakshaghata. So it is bagged in the present study for treatment purpose. In pakshagata, snehana and snehayuktavirechana explained by acharyavagbhata.Eranda is said to be sresthavatahara\&taila is considered best to combat aggravated vata. For that, in this study Erandataila is taken for nityavirechana to the patient of Pakshaghat which consists the above \& fulfil both the needs. As per Vagbhatapurvakarma is not necessary for nityavirechana. Thus, considering the above fact a Clinical study to evaluate the efficacy of Virechana Karma in pakshaghata is planned along with its conceptual study as mentioned in Brihatrayee.

\section{KEYWORDS : Pakshaghata, Virechana, Erandataila}

\section{INTRODUCTION:}

Pakshagata is the disorder manifested due to vitiation of vata in association with pitta \&kapha in etiopathogenesis Vatadosha is vitiated due to dietary factors like excessive intake of foods having katu, tikta\&kashaya rasa. Vata also vitiated due to excessive strain \& stressful conditions of life \& irregularities in diet. When vitiated vata attains strength for \& external factors, it provocate\& interacts with raktadhatu.

The normal functions of sira, snayu\&khandara, which are upadhatus of raktadhatu, are impaired due to interaction of rakta with vata. This result in into loss of functions of half of the body.this painful condition is pakshagata. When pitta dosha is also vitiated along with vatadosha, burning sensation, irriation\& stroke are the

The most paradoxical thing about treatment of Pakshagata is "PakshagateVirechanam". Usually Virechana is the treatment for pittadosha but in this vatavyadhivirechana is more effective than basti, which is the treatment of choice for vatadosha because of the following points.

- Pakshavadha is basically a pranavayuveekar, the natural direction of pranavayu is from above downwards. In virechana this proper direction of pranavayu is achivedbetter thanbasti.

- In pakshavadhaupadhatus of rakta i.e. Sira and Kandara vitiated for upadhatu treatment is given for main dhatu and treatment for raktadhatu is raktamokshana and virechana, therefore viechana is useful inpakshavadha.

- Virechana, the main line of treatment cannot be applied in SuddhaVata condition. Virechana is the line of treatment for VataVyaadhi condition where Vata is associated with Kapha,Pitta, Rakta and Meda. Highly effectiveness of Virechana in Pakshaaghaata supports the fact that its Samprapti is due to Aavarana of Vaata with Pitta, Rakta, Kapha and Meda.

- Pakshagata is also said to be a disease of majja vahasrotas. Majjadhatu and pitta are said to be form same origin 'Ya Eva Pittadharakalasa Eva Majja dharakala'. Therefore treatment for majja and virechana is best treatment for pitta. Therefore virechana is the treatment of choice inpakshagata.
- The adhishthana of Pakshaghata is Indriyayatana (Mastishka). Mastishka is referred as Mustulunga (Ch. Si. 9/101). Dalhana describes the word Mustulunga as Ghritakaram and MastishkaMajja (Su. Sha. 10/42, Dal.) He further describes MastishkaMajja as Majjadharakala and again says that Majjadharakala and pitta dharakala are one and the same. In pitta dharakalavikriti, Virechana is the best shodhanachikitsa. As Majjadharakala and pitta dharakala are same, Virechana may also act well in Majjadharakalavikriti. So, Virechana can be adopted in case ofPakshaghata.

- Kaphandubandhit and PittanubandhitPakshaghata have been described in MadhavaNidna. This can be compared with kaphavritta and pittavrittavata respectively. In treatment of both these conditions Virechana has been mentioned (Ch. Chi.28/184,185,189).

- Virechana Karma is a specific process for elimination of pitta dosha (Ch. Su25/40). It also eliminates kaphadosha either associated with pitta dosha or situated in pitta sthana (A.S. Su. 27). Virechana Karma is also said to be capable of mitigating vatadosha. MriduSanshodhanaa (Virechana) has been indicated for the treatment of vatadosha. (Ch. Vi. 6/16; A.H. Su. 13/1; Ch. Chi. 28/84). Hence dushti of all the three doshas is checked by thisKarma.

- In Pakshaghatathe main doshainvolved is vata. The natural abode of vatais Pakvashara(A.H Su. 12/1). In Pakvashayagatavata, Virechanais indicated. (Su. Chi.4/5).

- In case of Sansargajadosha, i.e., if vatais affected by pitta and kaphaboth, then pitta should be controlled first (Ch. Chi. 28/188) and for controlling pitta, Virechanais considered to be best. Hence in Doshanubandhita PakshaghataVirechanacan be considered as atreatment

- Vagbhata has mentioned Mridu Sanshodhanaa (Virechana) in the general line of treatment of vata(A.H. Su.13/1), which can also be adopted forPakshaghata.

- MriduSanshodhanaahas been mentioned in treatment of Margavarna. (Ch. Chi. 9/25). Hence in margavaranjanya Pakshaghata MriduSanshodhanaa, i.e., Virechanacan beadvocated.

- Majjavahasrotodushti takes place in Pakshaghata and in order to combat the morbidity related to Majja, timely 
shuddhi has been mentioned. (Ch. Su. 28/28). So here Virechana can be taken as a shodhanameasure.

- If we see the general line of treatment for vatavyadhi given by Acharya Charaka in Chikitsasthana $28^{\text {th }}$ chapter, then after snehana and Swedana, Virechana has been mentioned as main shodhana measure. In the patients contraindicated for Virechana, vasti has been mentioned. Hence Virechana is considered to be treatment of choice in vatavyadhi and so inPakshaghata.

- Virechana Karma possesses the property of purifying the vitiated dhatus (Ka. Si). It has been advised as a treatment in all dhatudushtijanyavikaras, viz., Rakta, Mansa, Meda, Majja, Shukragatavikaras. (Ch. Su. 28/25) Srotovishuddhi, Impairment of function of Mana, BuddhiPrasadana, impairment of Indriyas encountered in Pakshaghata, sanga type of srotodushti encountered in Pakshaghata are checked by virechana. Virechana imparts strength to the body and stabilizes all the dhatus. Hence useful in dhatukshayajanyaPakshaghata. (Ch. Si. 1/17; Su. Chi. 33/27; A.H. Su.18/60).

- Therefore by all the above statements it can be concluded that Virechana is the best Shodhana for Pakshaghata.

\section{MATERIALS \& METHODS:}

A total number of 40 patients will be taken for study. Patient will be randomly allocated into two groups. 20 patients will be placed under group-A and another 20 patients will be placed under group-B. In group- $\bar{A}$, patient will be advised to continue previous medication and in group- $B$, patient will be given Erandataila along with previous medication.

The Erandataila will be given orally with lukewarm water (12ml after food once for 15 days) for Group B.

\section{METHODS OF CLINICAL TRIAL:}

- Type of study- control study having 2 groups, trial group and control group.

- Level of study- OPD/IPD,

- Sample size- 40

- Duration: 15 days

- Dose- $12 \mathrm{ml}$ in one dose

- Follow up: In $7^{\text {th }}$ day and $15^{\text {th }}$ day.

- Anupana: luke warm water

\section{INCLUSION CRITERIA:}

- Patients diagnosed as Pakshaghata (hemiplegia)

- Age group of 35-65 years.

- Mild to moderate hypertensive will be considered.

- In case of the patients of pakshagata of sudden onset if there is unstable hypertension, such conditions will be stabilized with appropriate treatment and later taken up for the study.

\section{EXCLUSION CRITERIA:}

- Patients of Intracranial infection

- Intracranial space occupying lesions and truma.

- Patient with altered sensorium.

- Uncontrolled Diabetes mellitus

- Severe metabolic disorders

- Pregnant ladies

- Patient below the age of $30 y$ rs and above $60 y$ rs.

\section{WITHDRAWAL CRITERIA}

- If the patient discontinue during treatment.

- If found any intolerance of the drug the patient will be discontinued from the trial.

- Any complication arises the patient will be excluded from the study.

Assessment Parameters:

- Superficial Reflexes

- Muscle Tone
- Muscle Strength

- Finger Movement

- Loss of Speech

- Lifting of Arm at Shoulder

- Standing from Sitting

- Paper Holding

Investigations:

- Blood R/E

- Blood Sugar-RBS

- Lipid Profile

- Serum creatinine and Blood Urea

- Serum Electrolyte

- ECG

- C.T Scan of Brain if needed

A comprehensive clinical examination was done before and after treatment as per the Standard symptom scoring.

\begin{tabular}{|c|c|}
\hline Reflexes & Score \\
\hline Äbsent & 0 \\
\hline Present & 1 \\
\hline Brisk & 2 \\
\hline Very brisk & 3 \\
\hline Clonus & 4 \\
\hline Muscle tone & Score \\
\hline No increase & 0 \\
\hline Slight increase with catch and release & 1 \\
\hline Minimal resistance through range following Catch & 2 \\
\hline $\begin{array}{l}\text { More marked increase tone through Range of } \\
\text { Movement }\end{array}$ & 3 \\
\hline $\begin{array}{l}\text { Considerable increase in tone, passive movement } \\
\text { difficult }\end{array}$ & 4 \\
\hline Affected part rigid & 5 \\
\hline Muscle strength & Score \\
\hline Normal power & 5 \\
\hline Diminished & 4 \\
\hline Movement against gravity & 3 \\
\hline Movement with gravity eliminated & 2 \\
\hline Flicker with attempting movement & 1 \\
\hline No movement & 0 \\
\hline Finger Movement & Score \\
\hline No movement & 0 \\
\hline Slight movement & 1 \\
\hline Unable to hold the object & 2 \\
\hline Able to hold with less power & 3 \\
\hline Normal & 4 \\
\hline Loss of Speech & Score \\
\hline Global aphasia & 4 \\
\hline Utter voice & 3 \\
\hline Speak few words & 2 \\
\hline Speak with difficulty & 1 \\
\hline Normal & 0 \\
\hline Lifting of arm at Shoulder & Score \\
\hline No & 0 \\
\hline Upto 450 & 1 \\
\hline Upto 900 & 2 \\
\hline Upto 1350 & 3 \\
\hline Upto 1800 & 4 \\
\hline Standing from sitting & Score \\
\hline Unable & 2 \\
\hline With support & 1 \\
\hline Without support & 0 \\
\hline Paper holding & Score \\
\hline Normal & 2 \\
\hline Patient holds gently & 1 \\
\hline Patient fails to hold paper & 0 \\
\hline
\end{tabular}


OBSERVATIONS \& RESULTS

Age wise distribution of 40 patients

\begin{tabular}{|l|l|l|l|l|l|l|}
\hline Age & Group A & \multicolumn{4}{|l|}{ Group B } & \multicolumn{2}{l|}{ Over all } \\
\cline { 2 - 6 } & No. of patient & $\%$ & No. of patient & $\%$ & No. of patient & $\%$ \\
\hline $\begin{array}{l}35-45 \\
\text { years }\end{array}$ & 03 & 15 & 01 & 5 & 4 & 10 \\
\hline $\begin{array}{l}45-55 \\
\text { years }\end{array}$ & 07 & 35 & 05 & 25 & 12 & 30 \\
\hline $\begin{array}{l}55-65 \\
\text { years }\end{array}$ & 10 & 50 & 14 & 70 & 24 & 60 \\
\hline
\end{tabular}

Out of 40 patients studied in this series, maximum number of patients, i.e. 24 patients (60\%) were from age group 55-65 years 12 patients (30\%) were from age group $45-55$ years as well as, 04 patients were from the age group of $35-45$ years.

Age wise distribution of 40 patients

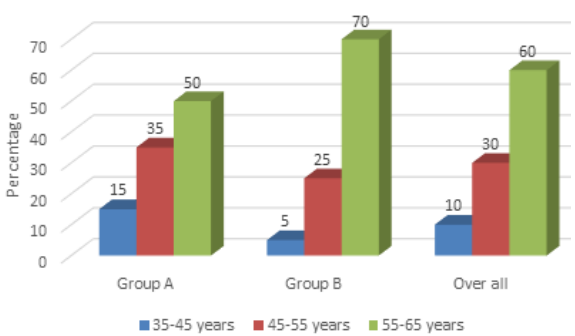

Sex wise distribution of 40 patients

\begin{tabular}{|c|c|c|c|c|c|c|}
\hline \multirow[t]{2}{*}{ Sex } & \multicolumn{2}{|l|}{ Group A } & \multicolumn{2}{|l|}{ Group B } & \multicolumn{2}{|l|}{ Over all } \\
\hline & No. of patient & & No. of patient & $\%$ & No. of patient & $\%$ \\
\hline Female & \begin{tabular}{|l|l}
08 & 4 \\
\end{tabular} & 40 & 02 & 10 & 10 & 25 \\
\hline Male & 12 & 60 & 18 & 90 & 30 & 75 \\
\hline
\end{tabular}

$25 \%$ of the patients were female, where $75 \%$ patients were male.

\section{Sex wise distribution of 40 patients}

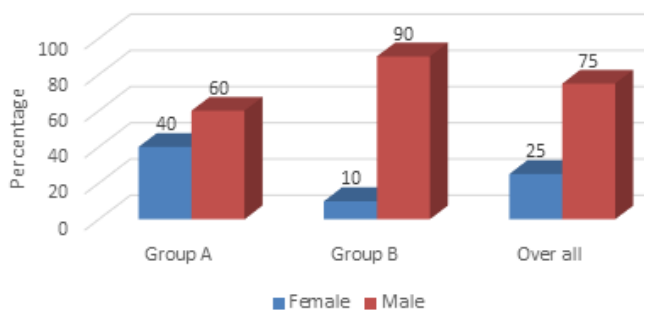

Habitat wise distribution of 40 patients

\begin{tabular}{|l|l|l|l|l|l|l|}
\hline \multirow{2}{*}{ Habitat } & Group A & \multicolumn{2}{|l|}{ Group B } & \multicolumn{2}{l|}{ Over all } \\
\cline { 2 - 6 } & No. of patient & $\%$ & No. of patient & $\%$ & No. of patient & $\%$ \\
\hline Urban & 16 & 80 & 08 & 40 & 24 & 60 \\
\hline Rural & 04 & 20 & 12 & 60 & 16 & 40 \\
\hline
\end{tabular}

Out of 40 patients 24 patients $(60 \%)$ were urban habitat where as 16 patients $(40 \%)$ were having rural habitat.

\section{Habitat wise distribution of 40 patients}

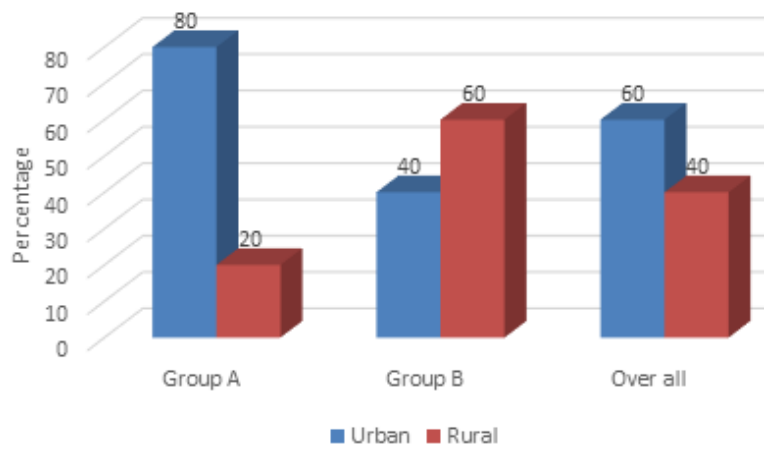

Kostha wise distribution of 40 patients

\begin{tabular}{|c|c|c|c|c|c|c|}
\hline \multirow[t]{2}{*}{ Kostha } & \multicolumn{2}{|c|}{ Group A } & \multicolumn{2}{|c|}{ Group B } & \multicolumn{2}{|c|}{ Over all } \\
\hline & \begin{tabular}{|l|} 
No. of \\
patient
\end{tabular} & $\%$ & $\begin{array}{l}\text { No. of } \\
\text { patient }\end{array}$ & $\%$ & $\begin{array}{l}\text { No. of } \\
\text { patient }\end{array}$ & $\%$ \\
\hline Mridu & 10 & 50 & 13 & 65 & 23 & 57.5 \\
\hline Madhyama & 07 & 35 & 02 & 10 & 09 & 22.5 \\
\hline Krvora & 03 & 15 & 05 & 25 & 08 & 20 \\
\hline
\end{tabular}

Most of the patients i.e. 23 patients (57.5\%) had mridukostha, while 09 patients (22.5\%) had madhyamakustha and 08 patients $(20 \%)$ had krvorakustha.

Kostha wise distribution of 40 patients

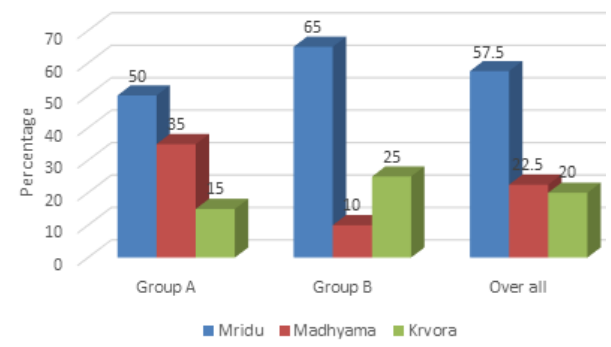

Education status wise distribution of 40 patients

\begin{tabular}{|l|l|l|l|l|l|l|}
\hline \multirow{2}{*}{$\begin{array}{l}\text { Educational } \\
\text { status }\end{array}$} & \multicolumn{2}{|l|}{ Group A } & \multicolumn{2}{l|}{ Group B } & \multicolumn{2}{l|}{ Over all } \\
\cline { 2 - 7 } & $\begin{array}{l}\text { No. of } \\
\text { patient }\end{array}$ & $\%$ & $\begin{array}{l}\text { No. of } \\
\text { patient }\end{array}$ & $\%$ & $\begin{array}{l}\text { No. of } \\
\text { patient }\end{array}$ & $\%$ \\
\hline Illiterate & 04 & 20 & 02 & 10 & 06 & 15 \\
\hline Primary & 03 & 15 & 08 & 40 & 11 & 27.5 \\
\hline $\begin{array}{l}\text { Higher } \\
\text { Secondary }\end{array}$ & 06 & 30 & 05 & 25 & 11 & 27.5 \\
\hline Graduate & 07 & 35 & 05 & 25 & 12 & 30 \\
\hline
\end{tabular}

Out of 40 patients studied in this series, maximum number of patients i.e. 12 patients $(30 \%)$ were graduates, while 11 patients $(27.5 \%)$ had higher secondary school level education and 11 patients $(27.5 \%)$ were primary school level of attraction and 06 patients $(15 \%)$ were illiterate.

Education status wise distribution of 40 patients

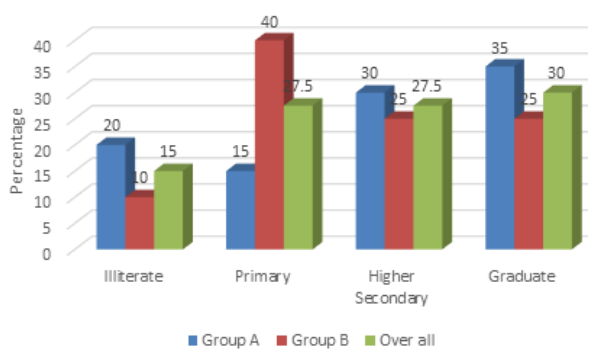

Distribution of 40 patients according to nature of work/ occupation

\begin{tabular}{|l|l|l|l|l|l|l|}
\hline Nature of work & \multicolumn{3}{|l|}{ Group A } & \multicolumn{2}{l|}{ Group B } & \multicolumn{2}{l|}{ Over all } \\
\cline { 2 - 7 } & $\begin{array}{l}\text { No. of } \\
\text { patient }\end{array}$ & $\%$ & $\begin{array}{l}\text { No. of } \\
\text { patient }\end{array}$ & $\%$ & $\begin{array}{l}\text { No. of } \\
\text { patient }\end{array}$ & $\%$ \\
\hline Laborious & 12 & 60 & 06 & 30 & 18 & 45 \\
\hline Active & 06 & 30 & 10 & 50 & 16 & 40 \\
\hline Sedentary & 02 & 10 & 04 & 20 & 06 & 15 \\
\hline
\end{tabular}

Maximum number of patients i.e. 18 (45\%) had laborites work, followed by 16 patients (40\%) who had active work style, whereas 6 patients (15\%) had sedentary work style.

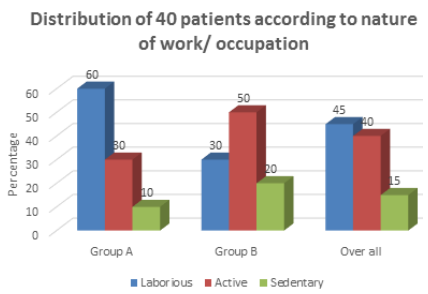

Dehaprakriti wise distribution of total 40 patients 


\begin{tabular}{|l|l|l|l|l|l|l|}
\hline Dehaprakriti & \multicolumn{2}{|l|}{ Group A } & \multicolumn{2}{l|}{ Group B } & \multicolumn{2}{l|}{ Over all } \\
\cline { 2 - 7 } & $\begin{array}{l}\text { No. of } \\
\text { patient }\end{array}$ & $\%$ & $\begin{array}{l}\text { No. of } \\
\text { patient }\end{array}$ & $\%$ & $\begin{array}{l}\text { No. of } \\
\text { patient }\end{array}$ & $\%$ \\
\hline Pitta- kaphaja & 03 & 15 & 05 & 25 & 08 & 20 \\
\hline Vatakaphaja & 05 & 25 & 06 & 30 & 11 & 27.5 \\
\hline Vata-pittaja & 12 & 60 & 09 & 45 & 21 & 52.5 \\
\hline
\end{tabular}
patients

Majority of the patients were it vata-pittaja $(52.5 \%)$ whereas 11 patients had (27.5\%) vata-kaphaprakriti and 08 patients (20\%) had pitta kaphaprakriti.

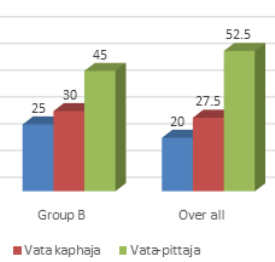

Comparative efficacy of Group A and Group B

Paired $t$ test for group A:

\begin{tabular}{|l|l|l|l|l|l|l|l|l|l|l|}
\hline Parameters & $\mathrm{X}_{\mathrm{BT}}$ & $\mathrm{x}_{\mathrm{AT}}$ & $\mathrm{SD}_{\mathrm{BT}}$ & $\mathrm{SD}_{\mathrm{AT}}$ & $\mathrm{SEM}_{\mathrm{BT}}$ & $\mathrm{SEM}_{\mathrm{AT}}$ & $\mathrm{SED}$ & $\mathrm{T}_{19}$ & $\mathrm{P}$ & $\mathrm{R}$ \\
\hline Superficial reflexes & 0.25 & 0.70 & 0.44 & 0.73 & 0.10 & 0.16 & 0.114 & 3.9428 & $\mathrm{P}<0.01$ & $\mathrm{SHS}$ \\
\hline Muscle tone & 0.40 & 0.65 & 0.50 & 0.59 & 0.11 & 0.13 & 0.009 & 2.5166 & $\mathrm{P}<0.05$ & $\mathrm{SHS}$ \\
\hline Muscle strength & 0.15 & 0.90 & 0.37 & 0.97 & 0.08 & 0.22 & 0.190 & 3.9428 & $\mathrm{P}<0.01$ & $\mathrm{SHS}$ \\
\hline Finger movement & 0.35 & 1.10 & 0.59 & 0.91 & 0.13 & 0.20 & 0.143 & 5.2517 & $\mathrm{P}<0.01$ & $\mathrm{SHS}$ \\
\hline Loss of speech & 3.65 & 3.45 & 0.67 & 1.1 & 0.15 & 0.25 & 0.117 & 1.7 & $\mathrm{p}>0.05$ & $\mathrm{SNS}$ \\
\hline Lifting of Arm at shoulder & 0.20 & 0.30 & 0.41 & 0.47 & 0.09 & 0.11 & 0.069 & 1.4530 & $\mathrm{p}>0.01$ & $\mathrm{SNS}$ \\
\hline Standing from sitting & 0.20 & 0.25 & 0.52 & 0.64 & 0.12 & 0.14 & 0.114 & 0.4381 & $\mathrm{p}>0.5$ & $\mathrm{SNS}$ \\
\hline Paper holding test & 0.30 & 0.40 & 0.47 & 0.60 & 0.11 & 0.13 & 0.124 & 0.8094 & $\mathrm{p}>0.1$ & $\mathrm{SNS}$ \\
\hline
\end{tabular}

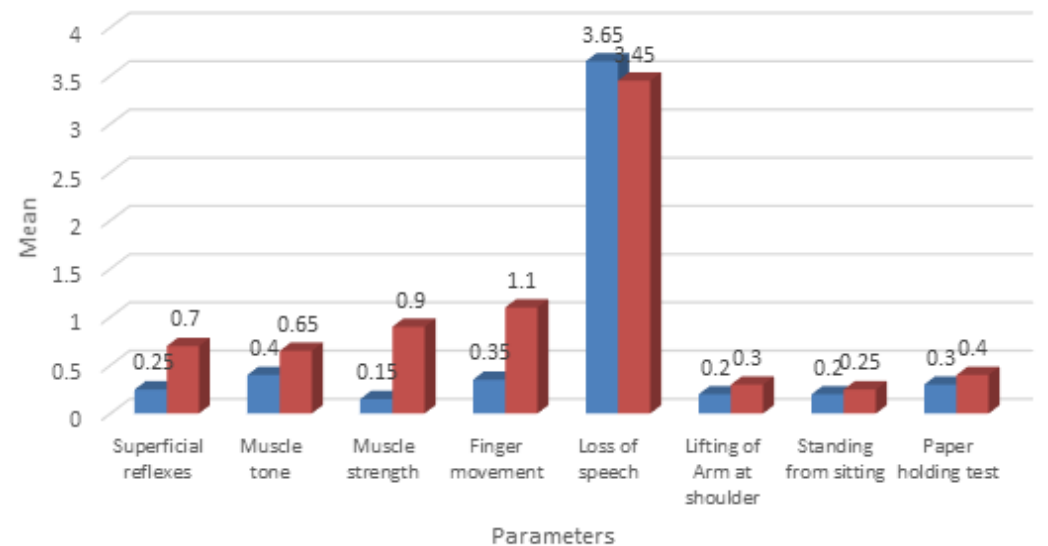

- Mean BT Mean AT

Paired t test for group B:

\begin{tabular}{|l|l|l|l|l|l|l|l|l|l|l|}
\hline Parameters & $\overline{\mathrm{x}}_{\mathrm{BT}}$ & $\overline{\mathrm{x}}_{\mathrm{AT}}$ & $\mathrm{SD}_{\mathrm{BT}}$ & $\mathrm{SD}_{\mathrm{AT}}$ & $\mathrm{SEM}_{\mathrm{BT}}$ & $\mathrm{SEM}_{\mathrm{AT}}$ & $\mathrm{SED}$ & $\mathrm{T}_{19}$ & $\mathrm{P}$ & $\mathrm{R}$ \\
\hline Superficial reflexes & 0.65 & 2.45 & 0.59 & 1.05 & 0.13 & 0.23 & 0.228 & 7.670 & $\mathrm{P}<0.001$ & $\mathrm{SHS}$ \\
\hline Muscle tone & 0.65 & 1.90 & 0.93 & 0.97 & 0.21 & 0.22 & 0.160 & 7.8037 & $\mathrm{P}<0.01$ & $\mathrm{SHS}$ \\
\hline Muscle strength & 0.50 & 2.20 & 0.69 & 1.01 & 0.15 & 0.22 & 0.147 & 11.5727 & $\mathrm{P}<0.01$ & $\mathrm{SHS}$ \\
\hline Finger movement & 0.60 & 1.75 & 0.69 & 1.07 & 0.15 & 0.24 & 0.182 & 6.3280 & $\mathrm{P}<0.01$ & $\mathrm{SHS}$ \\
\hline Loss of speech & 3.70 & 3.55 & 0.57 & 0.89 & 0.13 & 0.20 & 0.082 & 1.8311 & $\mathrm{P}>0.05$ & $\mathrm{SNS}$ \\
\hline Lifting of Arm at shoulder & 0.25 & 0.30 & 0.44 & 0.57 & 0.17 & 0.13 & 0.088 & 0.5675 & $\mathrm{p}>0.01$ & $\mathrm{SNS}$ \\
\hline Standing from sitting & 0.25 & 0.30 & 0.55 & 0.57 & 0.12 & 0.13 & 0.135 & 0.3697 & $\mathrm{p}>0.5$ & $\mathrm{SNS}$ \\
\hline Paper holding test & 0.35 & 0.45 & 0.59 & 0.60 & 0.13 & 0.14 & 0.176 & 0.5675 & $\mathrm{p}>0.10$ & $\mathrm{SNS}$ \\
\hline
\end{tabular}

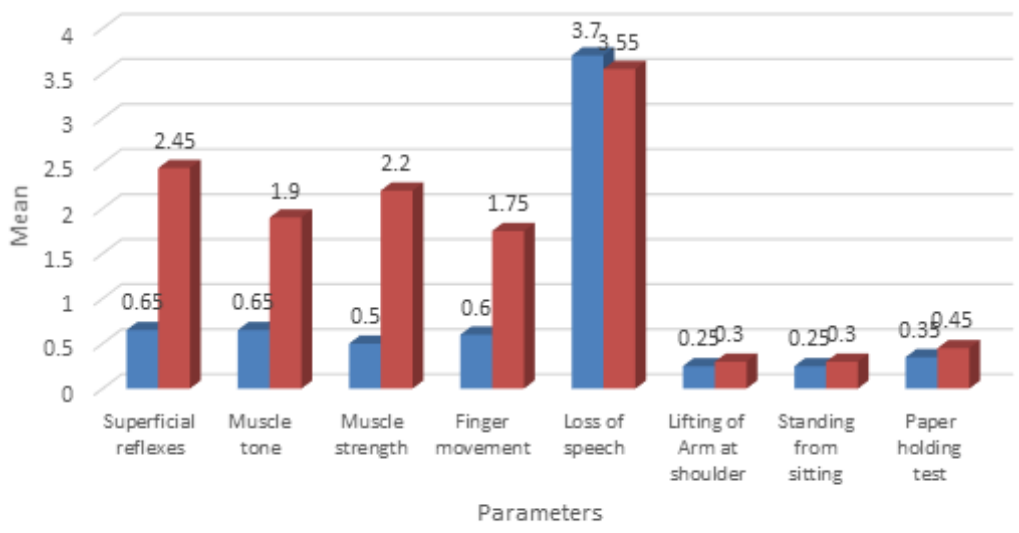


Unpaired t test for group $\bar{A}$ and group $B$ :

\begin{tabular}{|l|l|l|l|l|l|l|l|l|l|l|}
\hline Parameters & $\mathrm{x}_{\bar{A}}$ & $\overline{\mathrm{x}}_{\mathrm{B}}$ & $\mathrm{SD}_{\overline{\mathrm{A}}}$ & $\mathrm{SD}_{\mathrm{B}}$ & $\mathrm{SEM}_{\bar{A}}$ & $\mathrm{SEM}_{\mathrm{B}}$ & $\mathrm{SED}$ & $\mathrm{T}_{38}$ & $\mathrm{P}$ & $\mathrm{R}$ \\
\hline Superficial reflexes & 0.45 & 1.75 & 0.51 & 1.02 & 0.11 & 0.23 & 0.255 & 5.0990 & $\mathrm{P}<0.01$ & $\mathrm{SHS}$ \\
\hline Muscle tone & 0.25 & 1.25 & 0.44 & 0.72 & 0.10 & 0.16 & 0.188 & 5.3055 & $\mathrm{P}<0.01$ & $\mathrm{SHS}$ \\
\hline Muscle strength & 0.75 & 1.70 & 0.85 & 0.66 & 0.19 & 0.15 & 0.240 & 3.9527 & $\mathrm{P}<0.001$ & $\mathrm{SHS}$ \\
\hline Finger movement & 0.75 & 1.15 & 0.64 & 0.81 & 0.14 & 0.18 & 0.231 & 1.7306 & $\mathrm{P}<0.05$ & $\mathrm{SHS}$ \\
\hline Loss of speech & 0.20 & 0.10 & 0.52 & 0.31 & 0.12 & 0.07 & 0.136 & 0.7368 & $\mathrm{p}>0.05$ & $\mathrm{SNS}$ \\
\hline Lifting of Arm at shoulder & 0.10 & 0.15 & 0.31 & 0.37 & 0.07 & 0.08 & 0.107 & 0.4673 & $\mathrm{p}>0.05$ & $\mathrm{SNS}$ \\
\hline Standing from sitting & 0.15 & 0.25 & 0.49 & 0.55 & 0.11 & 0.12 & 0.165 & 0.6074 & $\mathrm{p}>0.10$ & $\mathrm{SNS}$ \\
\hline Paper holding test & 0.30 & 0.50 & 0.47 & 0.61 & 0.11 & 0.14 & 0.172 & 1.1650 & $\mathrm{p}>1.0$ & $\mathrm{SNS}$ \\
\hline
\end{tabular}

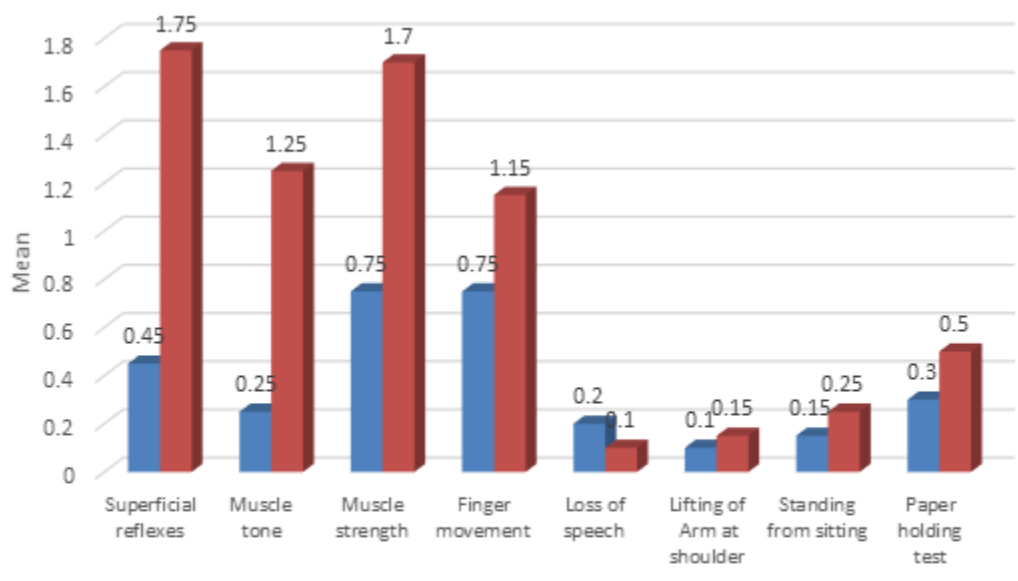

Parameters

- Mean A Mean B

On Superficial Reflexes : In group A mean 0.45, SD 0.51, SEM 0.11 while in Group B mean 1.75, SD 1.02, SEM 0.23. The comparative efficacy of Group A and Group B was statistically significant $(p<0.01)$ with SED 0.255 and t value 5.0990

On Muscle Tone : : In group A mean 0.25, SD 0.44, SEM 0.10 while in Group B mean 1.25, SD 0.72, SEM 0.16. The comparative efficacy of Group A and Group B was statistically significant $(p<0.01)$ with SED 0.188 and t value 5.3055

On Muscle Strength : In group A mean 0.75, SD 0.85, SEM 0.19 while in Group B mean 1.70, SD 0.66, SEM 0.15. The comparative efficacy of Group A and Group B was statistically significant $(p<0.001)$ with SED 0.240 and t value 3.9527

On Finger Movement : In group A mean 0.75, SD 0.64, SEM 0.14 while in Group B mean 1.15, SD 0.81, SEM 0.18. The comparative efficacy of Group A and Group B was statistically significant $(p<0.05)$ with SED 0.231 and t value 1.7306

On Loss of Speech : In group A mean 0.20, SD 0.52, SEM 0.12 while in Group B mean 0.10, SD 0.31, SEM 0.07. The comparative efficacy of Group A and Group B was statistically Not significant $(p>0.05)$ with SED 0.136 and t value 0.7368

On Lifting of Arm at Shoulder : : In group A mean 0.10, SD 0.31, SEM 0.07 while in Group B mean 0.15, SD 0.37, SEM 0.08. The comparative efficacy of Group A and Group B was statistically Not significant $(p>0.05)$ with SED 0.107 and t value 0.4673

On Standing from Sitting : : In group A mean 0.15, SD 0.49, SEM 0.11 while in Group B mean 0.25, SD 0.55, SEM 012. The comparative efficacy of Group A and Group B was statistically Not significant $(p>0.10)$ with SED 0.165 and t value 0.6074

On Paper Holding : In group A mean 0.30, SD 0.47, SEM 0.11 while in Group B mean 0.50, SD 0.61, SEM 0.14. The comparative efficacy of Group A and Group B was statistically
Not significant $(\mathrm{p}>1.0)$ with SED 0.172 and t value 1.1650

\section{DISCUSSION:}

Pakshaghata is one among the Vatavyadhi characterized by cheshtanivruti. But this Mahagada is having much more drastic expression on human life. The tragedy of theCerebro Vascular Accidents lies in the fact that it does not always kill rapidly in fact it is the chief and most crippling diseases destroying body and mindalike.

Chikitsa in Ayurvedic terms not only aims at the radical removal of the disease but also guides for the restoration and maintenance of normal health. Virechana is one among the treatment modality forPakshaghata.

PakshagateVirechana has been selected for the study. While screening the literatures it can be found that swedana and snigdhavirechana in pakshagata which pacifies the vitiated Vatadosha. Pakshaghata is vata-dominating disease even though the basti karma is given prime shodhana karma instead of this charaka and vagbhata have advisededVirechana is specific shodhana for Pakshaghata.

Both the group showed statistically significant result though in comparative study result in Group B was better than Group A. So virechana (erandataila) have good rule in Pakshaghat.

\section{CONCLUSION:}

Virechana karma is one among the shodhana. Even though Virechana is best line of treatment modality for pittadosha it can act on kaphasamsrusta pitta or pittasthanagatkapha. And moreover in case of vatasyopakramamridushodhana indicated which refers to mriduvirechanakarma.SoVirechana is major line of treatment for morbid pittadosha\& also it act on morbid kapha\&vatadosha. Thus Virechana action seen on all tridosha.

- The study showed significant result for both the groups.

- B group result was better in the comparative study. It showed that Virechana having effect on management of 
Pakshaghat.

Same study can be taken up for further study with large sample size and with larger duration of therapy.

\section{REFERENCES}

1) Agnivesh "CharakaSamhita", Revised by Charaka and Dridhabala with the Ayurveda Dipika commentary of Chakrapanidatta, Reprint 2004, ChoukhambhaSamskritSamsthana, and Varanasi U.P.

2) Vagbhata Acharya "AstangaHrudayam" with SarvangaSundaraCommentry of Arunadatta and Ayurveda Rasayana Commentary of Hemadri-Reprint 2005, ChoukhambaOrienalia- Varanasi U.P.

3) Vagbhatacharya "AshtangaSangraha" withShasilekha Commentary of Indu, 1991,CCRAS Publication, New Delhi.

4) Acharya Sushruta "SushrutaSamhita" with NibandhaSangraha Commentary of Dalhana and the NyayachandrikaPanjika of Gayadasa on Chikitsa Sthana;6th edition, 1997, ChoukhambhaOrientalia-Varanasi U.P

5) Vriddhajivaka "KashyapaSamhita" Sddisthana 7th Chapter, Hindi Translation of Sanskrit Introduction by Ayurvedalankar ,Srisaty pala Bhisagacharya.

6) Sharangadhara, SharangadharaSamhita, Parshuram Pandit Shastri Vidhyasagar, ChoukhambhaOrientalia-Varanasi,6th Edition

7) Vriddhajivaka "KashyapaSamhita" Sddisthana 7th Chapter, Hindi Translation of Sanskrit Introduction by Ayurvedalankar ,Srisatypala Bhisagacharya.

8) Sharangadhara, SharangadharaSamhita, Parshuram Pandit Shastri Vidhyasagar, ChoukhambhaOrientalia-Varanasi,6th Edition

9) Vangasen"HindiCommentarybyKavivaraShree.Shaligramagivaishya Publication by KhemarajaShreekrishnadaasa Mumbai.

10) Satuskar RS, Bhandarkar SD, Ainapure SS. Pharmocology \& Pharmacotherapeutics chapter 33. 16th ed. Mumbai: Popular Prakashan Publications.1999.

11) Joel G Hardman and Lee E Limbird, Goodman and Gilman, The pharmacological basis of therapeutics, , 10thed, Mc. Graw Hill Book Company, Hamberg:2001.

Vachaspatyam - edited by Shri Taranatharaka Vachaspati Bhat, 3rd Edition, 1969, Chaukambha Sanskrit Series, Varanasi.

12) Shabdakalpadruma:Rajaradhakanthadeva: edited by Nag publishers ; New delhi, 1987.

13) VyavaharAyurved ;Vaidyapadade; edited by Choukambha Amar bharti publication pvt. Limited, Varanasi: 1966

14) Madhavakara; Madhavanidana: edited by Shastrisri Sudarshan, ChaukambhaSanskrisansthan. Varanasi, 2000

15) API text book of medicine; edited by Shantilalj.Shah, Association of physiciansof India Mumbai,-1988, 4th edition.

16) Ayurveda kaVaijnanikIthihas; edited by Sharma P.V.; Chaukambha Orientalia; Varanasi, 1981, second edition.

17) Rigveda samhita;Dixitendragovinda; edited by Sri govinda dixit harpuny asmaranasamithi;Kumbhakonam.

18) Atharvaveda: Devichandm.a: edited by Munshirammanoharlal publishers pvt.limited:New Delhi.

19) Prashnopanishath: Devichandm.a: edited by Munshirammanoharlal publishers pvt.limited: New Delhi.

20) History of Medicine in India: edited by Sharma P.V.; The Indian National Science Academy,Delhi, 1992

21) Garuda puran; edited by Acharya Baladevaupadhya: Chaukambha Sanskrit Varanasi, series: 1966

22) Vishnu puran: edited by Acharya Baladevaupadhya: Chaukambha Orientalia; Varanasi, 1966.

23) Agnivesha: Charakasamhitha, edited by Acharya JadavjiTrikamji, Choukambha publication, Varanasi.,2000.

24) Sushrutha: Sushruthsamhita: edited by Acharya JadavjiTrikamji, Choukambh publication, Varanasi.,2000.

25) Vagbhatacharya: Astangasangraha: edited by KavirajaAtridevaGupta; Krishnada Academy, Varanasi,2002.

26) Vagbhatacharya; AstangaHridaya, edited by Shastrikashinath, Choukambha Orientalia,Varanasi.,1998.

27) Bhavamisra; Bhavaprakasa, volume 2; edited by Mishra Brahmashankara; Chaukambha Sanskrit sansthan. Varanasi, 1993

28) Madhavakara; Madhavanidana: edited by Shastrisri Sudarshan, Chaukambha Sanskrit sansthan. Varanasi, 2000

29) API Text Book of Medicine : 7th Edition, edited by Dr. Siddharth N. Shah, TheAssiciation of Physicians, The National Book Depot, Mumbai.

30) Tortora/Grabowski, Principles of Anatomy \& Physiology ninth edition.

31) Vaghbata. Astangasangraha, Vol II. English translation by shrikanthmoorthy. Varanasi: ChaukambaOrientalia.

32) Agni-purana, Maharshi Veda Vyasa, lstedi.,AcharyaBaladevaUpadhyaya, Chaukhamba Sanskrit Series, Varanasi, 1996

33) Dr. Sharma P.V. Indian Medicine In The Classical Age" Choukhamba Amarabharati Prakashana; 2nd Edition.

34) Tarka Sri Taranatha ,Vachaspathyam, VachaspathhiChaukamba Varanasi 1962.

35) Deva Raja radhakantha "Shabdakalpadruma" Nag publishers ; New Delhi, 1987.

36) Harita. HaritaSamhita. edited by RamavalambaShastri. Prachya Prakashana. 1st Edition-1985. Varanasi

37) Yogaratnakara; edited by Indradevitripathi\& Dr. DayashankarTripathi; Krishnadas Academy; Varanasi; 1998.

38) Bhavaprakasha :BrahmasankaraMishrta\& Sri RupaLalajiVaishya; edited by Bhavamishra;; Chaukambha Sanskrit Sansthan. Varanasi,2004; 11th edition.

39) DhanwantrinighantuAcharayaPriyavrat Sharma; edited by Dr. Guruprasad Sharma; 3rd Edition;;ChaukhambaOrientalia; Varanasi; 2002

40) RajanighantuPanditNarhari; edited by Dr. Indradeotripathi;2nd edition; Chaukhamba press; Varanasi; 1998.
41) Dhanwantrinighantu; AcharayaPriyavrat Sharma; edited by Dr. Guruprasad Sharma; 3rd Edition; ChaukhambaOrientalia; Varanasi; 2002.

42) KaidevaNighantuAcharayaPriyavrata Sharma; edited by Dr. Guruprasad Sharma; lst Edition; ChaukhambaOrientalia; Varanasi; 1979.

43) Bhavaprakasha; BrahmasankaraMishrta\& Sri RupaLalajiVaishya; edited by Bhavamishra; ChaukambhaSanskritSansthan. Varanasi,2004; 1 lth edition. 